\title{
Spatiotemporal Variations of Adsorbed Nonpoint Source Nitrogen Pollution in a Highly Erodible Loess Plateau Watershed
}

\author{
Lei Wu ${ }^{1-3 *}$, Tong Qi ${ }^{1,3}$, Jin Zhang $^{4}$ \\ ${ }^{1}$ College of Water Resources and Architectural Engineering, Northwest A\&F University, \\ Yangling, 712100, P.R. China \\ ${ }^{2}$ State Key Laboratory of Soil Erosion and Dryland Farming on the Loess Plateau, Northwest A\&F University, \\ Yangling, 712100, P.R. China \\ ${ }^{3}$ Key Laboratory of Agricultural Soil and Water Engineering in Arid and Semiarid Areas Ministry of Education, \\ Northwest A\&F University, Yangling, 712100, P.R. China \\ ${ }^{4}$ Institute of Urban Water Management, Technische Universität Dresden, \\ Dresden 01062, Germany
}

Received: 30 August 2016

Accepted: 20 December 2016

\begin{abstract}
Soil erosion is the main pathway of nutrients to fresh water in highly erodible regions. In this study, a dynamic erosion-type nonpoint source (NPS) pollution model was proposed to investigate spatiotemporal characteristics of adsorbed NPS total nitrogen (TN) load before and after returning farmland. Results indicate that: 1) the erosion-type NPS TN load showed a significant decreasing trend since the implementation of a returning farmland project from 1997, where the average TN load in 2009-12 was $2719.7 \mathrm{t} / \mathrm{a}$, which decreased by about $80.7 \%$ compared with the initial period of governance (1995-98); 2) Spatial distributions of erosion-type NPS TN load are closely related to sediment yield, the high risk values of TN load mainly occur along the main river banks of the Yanhe River watershed from northwest to southeast; 3) Before returning farmland, the adsorbed NPS TN load in the Yanhe River upstream was relatively large, while after that it had a decreasing trend in the upper reaches of the Yanhe River watershed. Dry land is still a critical source area of NPS pollution load in the loess hilly and gully region. Therefore, it is essential to strengthen water conservation measures in highly erodible regions for the amelioration of regional water environment quality.
\end{abstract}

Keywords: erosion-type nonpoint source pollution, dynamic model, nitrogen loss, spatiotemporal characteristics, Yanhe River watershed

*e-mail: conquer2006@126.com 


\section{Introduction}

Soil loss has carried a lot of nutrients into natural water bodies, these materials carried by sediment and runoff are defined as erosion-type non-point source (NPS) pollution [1]. The Loess Plateau is one of the most serious soil loss regions in China and even the world [2], with its annual sediment discharge accounting for $90 \%$ of the total sediment loadings of the Yellow River [3], and severe soil loss leads to nitrogen and phosphorus loss of farmland [4]. Because the process of sediment yield is an important basis for the study of NPS pollution in highly erodible regions [5]. It is necessary to quantitatively study processes of erosion and sediment yield at watershed scale [6].

The modeling approach has been frequently used to quantify sediment yield and NPS pollution load on a basin scale [7-8]. Empirical models have been successfully applied to predict erosion and sediment yield in various regions [9-10]. In all empirical models, the universal soil loss equation (USLE) or its revised form [11] has been widely used to predict annual soil loss resulting from sheet and rill erosion at field scale, and now it has been dominantly applied in GIS-based soil erosion assessments of different catchment areas [12]. Considering the application limitation of the USLE model in different sloping gradient conditions, Liu et al. (2001) put forward the Chinese soil loss equation (CSLE) with a simple structure that is suitable for most areas of China [13]. Through the application of the CSLE model in small watersheds in Shanxi and Beijing of China [14-15], the simulated results were not much different from the experimental data, so the CSLE model has a certain representative in the quantitative research aspects of soil erosion in China. In view of the fact that large amount of NPS pollutants are carried by sediment in highly erodible regions, relevant scholars have established different adsorbed NPS pollution models to simulate spatiotemporal characteristics of nitrogen and phosphorus loads [16-20]. However, most of these models are empirical equations that are used to predict the long-term average load - not to simulate dynamic and continuous changes [21]. This is necessary for predicting NPS pollution load by considering dynamic changes of hydrological characteristics and underlying conditions.

Land use change can alter hydrological and ecological conditions [22-23], and it has become an important factor affecting NPS pollution load into a river [2428]. The relationship between land use change and NPS pollution has been considered a focus issue in reseaching watershed management [29]. Due to severe soil loss in the Chinese Loess Plateau, the central and local governments in China have attached great attention to the ecological environmental construction in the Loess Plateau since the founding of new China (1949). The land use change due to the Grain for Green Project between 1980 and 2005 show significant effects on sediment reduction in China [30]. The Yanhe River watershed is one of the fastest implementation areas for returning farmland to forest (grassland), and soil erosion control has entered a new
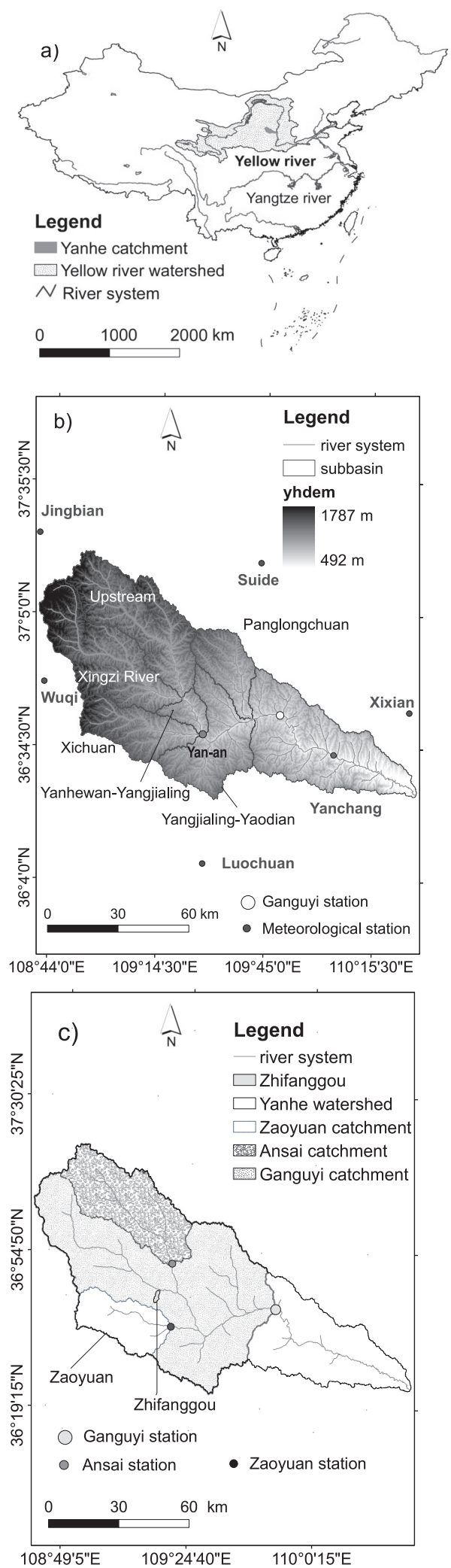

Fig. 1. The study area: a) the relative location between the study area and the Yellow River Basin in China; b) longitude and latitude coordinates of the study area, digital elevation model (DEM) data, meteorological station, and the delineation of subbasin and river systems within the Yanhe River watershed; and c) the relative location of Zhifanggou watershed, catchment of Ansai Hydrological Station, catchment of Zaoyuan Hydrological Station, upper reaches of Ganguyi Hydrological Station, and Yanhe River watershed. 
Table 1. Descriptions and sources of environmental data in the Yanhe River watershed.

\begin{tabular}{|c|c|c|c|}
\hline Data layer & Format & Description & Source \\
\hline DEM & Raster & $\begin{array}{c}30 \mathrm{~m} \text { spatial resolution DEM data of the Yanhe } \\
\text { River watershed }\end{array}$ & $\begin{array}{c}\text { Computer Network Information Center, Chinese } \\
\text { Academy of Sciences: } \\
\text { http://datamirror.csdb.cn/index.jsp }\end{array}$ \\
\hline Land use & Raster & $\begin{array}{l}\text { Farmland, grassland, forest land, residential area, } \\
\text { water area, sandy land (30 m spatial resolution) }\end{array}$ & $\begin{array}{l}\text { Data Center for Cold and Arid Regions } \\
\text { Sciences: westdc.westgis.ac.cn }\end{array}$ \\
\hline Precipitation & DBF & $\begin{array}{l}\text { Daily values of precipitation in Jingbian, } \\
\text { Ansai, Yanan, Wuqi, Suide, Zaoyuan, Ganguyi, } \\
\text { Yanchang, Xixian, Luochuan (1995-2012) }\end{array}$ & $\begin{array}{c}\text { China Meteorological Data Sharing Service } \\
\text { Network } \\
\text { http://www.cdc.sciencedata.cn }\end{array}$ \\
\hline Soil & DBF & $\begin{array}{l}\text { Soil physical and chemical properties in the } \\
\text { Loess Plateau }\end{array}$ & \multirow{2}{*}{$\begin{array}{c}\text { National Science and Technology Infrastructure } \\
\text { of China, Data Sharing Infrastructure of Earth } \\
\text { System Science: www.geodata.cn }\end{array}$} \\
\hline $\begin{array}{l}\text { Hydrological } \\
\text { data }\end{array}$ & Excel & $\begin{array}{c}\text { Time series of daily observed values of runoff } \\
\text { and sediment amount in Ganguyi hydrological } \\
\text { station (1954-2012) }\end{array}$ & \\
\hline
\end{tabular}

stage since the implementation of the Returning Farmland Project in 1997 [31-32], and great changes have taken place in land use patterns in the watershed.

In this study, the Yanhe river watershed was selected as the research object to study impacts of revegetation on spatiotemporal characteristics of adsorbed NPS TN load in semi-arid regions. The dynamic model of adsorbed NPS load based on the CSLE model and GIS technology was established to estimate adsorbed NPS TN load (1995-2012) and elucidate spatiotemporal characteristics before and after returning farmland, results from which may provide scientific reference for the control of NPS pollution and the protection of river ecosystems in loess hilly and gully regions.

\section{Material and Methods}

\section{Study Area}

The Yanhe River, which originates in Baiyu Mountain of Jingbian County, is one of the main tributaries in the right shore of the Yellow River (Fig. 1a). The Yanhe River watershed, which is located $108^{\circ} 38^{\prime}-110^{\circ} 29^{\prime} \mathrm{E}$ and $36^{\circ} 21^{\prime}-37^{\circ} 19^{\prime} \mathrm{N}$ (Fig. 1b), has a watershed area of $7,725 \mathrm{~km}^{2}$. The watershed has criss-cross ravines and gullies, broken terrain, and low vegetation coverage, and is one of the most typical erosion-type basins in the hilly and gully loess region of the Loess Plateau. The average annual temperature is $8.8-10.2^{\circ} \mathrm{C}$, average annual precipitation is about $495.6 \mathrm{~mm}$, and almost $70 \%$ of the total annual rainfall occurs from June to September. Soils in the watershed mainly consist of alluvial soil, clay soil, and Heilu soil, where the most widely seen soil is alluvial.

\section{Data Sources}

The data included in modeling adsorbed NPS TN load include digital elevation model (DEM), meteorological data, hydrological data, land use, and soil properties (Table 1 and Fig. 1c).

\section{Methodology \\ Dynamic Erosion-Type NPS Pollution Model}

Based on sediment yield, the background content of TN in topsoil, and the enrichment ratio of TN in sediments, the dynamic model of erosion-type NPS pollution was established as follows:

$$
L_{n, i}=Q_{s, i} \times C_{n} \times \eta_{n}
$$

...where $L_{n, i}$ is the adsorbed TN load in the $i$-th year (t/a), $Q_{s, i}$ is the annual sediment yield amount (t/a), $C_{n}$ is the background content of TN in topsoil $\left(\mathrm{g} \mathrm{kg}^{-1}\right)$, and $\eta_{n}$ is the enrichment ratio of TN in sediments (-).

The erosion-type NPS pollution is closely associated with the process of erosion and sediment yield. Considering that the CSLE equation reflects the multiyear average sediment yield amount, it does not express the dynamic variations of erosion and sediment yield. On the basis of dynamic estimation methods of soil erosion studied by the related scholars [33-34], the rainfall erosivity factor and the sediment delivery ratio factor affected by the hydrological factors were designed as the hydrological dynamic factor; biological measures, engineering measures, tillage measures, and the sediment delivery ratio factor affected by land management factors were defined as the dynamic influencing factor of human activities, so the dynamic model of sediment yield was put forward as follows:

$$
Q_{s, i}=A \times K \times L S \times\left(R_{i} \times \lambda_{q, i}\right) \times\left(B_{i} \times E_{i} \times T_{i} \times \lambda_{m, i}\right)
$$

...where $A$ is the catchment area $\left(\mathrm{hm}^{2}\right) ; R$ is the rainfall erosivity factor $\left(\mathrm{MJ} \cdot \mathrm{mm} / \mathrm{hm}^{2} \cdot \mathrm{h} \cdot \mathrm{a}\right) ; K$ is the soil erodibility factor $\left(\mathrm{t} \cdot \mathrm{hm}^{2} \cdot \mathrm{h} / \mathrm{hm}^{2} \cdot \mathrm{MJ} \cdot \mathrm{mm}\right) ; \mathrm{L}$ is the slope length factor; $S$ is the slope gradient factor; $B$ is the biological measure factor; $E$ is the engineering measure factor; $T$ is the tillage 
measure factor; $L, S, B, E$, and $T$ are all dimensionless; $\lambda$ is the sediment delivery ratio; and subscript $i$ represents the $i$-th year - supposing that factor $\lambda_{i}$ can be approximately divided into the product of $\lambda_{q, i}$ related only to hydrological conditions and $\lambda_{m, i}$ related only to land management measures.

Impacts of hydrological factors on sediment yield are mainly manifested in the moving action of sediment from erosion occurrence to the river course by rainfall runoff. $\lambda_{q, i}$ can be estimated by the sediment transport capacity that is widely used in hillslope and fluvial geomorphology [35]. The equation of $\lambda_{q, i}$ can be expressed as:

$$
\lambda_{q, i}=\left(\frac{q_{i}}{q}\right)^{1.45} \cdot \lambda_{q}
$$

...where $q$ and $q_{i}$ represent the average annual runoff amount per unit width $\left(\mathrm{m}^{-3}\right)$ and the runoff amount per unit width in the $\mathrm{i}$-th year $\left(\mathrm{m}^{-3}\right)$, respectively; $\lambda$ represents the sediment delivery ratio impacted by hydrological factors.

Impacts of land management measures on sediment transport are mainly demonstrated in water and sediment reduction effects by all kinds of soil and water conservation measures. Under the annual changing conditions of $\lambda_{m, i}$, $B, E$, and $T$, the dynamic influencing factor of human activities was introduced and defined as:

$$
\delta_{i}=\frac{B_{i} \times E_{i} \times T_{i} \times \lambda_{m, i}}{B \times E \times T \times \lambda_{m}}
$$

In order to quantitatively study impacts of land management activities on the sediment transport process, according to the previous research results of runoff and sediment characteristics in the Yanhe River watershed from 1956 to 2009 [36], the years 1956-69 are regarded as the sporadic governance stage with little intervention of human activities, and the years after the 1970s may be defined as the governance period with the gradually increased impact of human activities. Based on the related literature [37-39], the fitting relationship expressions of runoff and sediment from Ganguyi hydrological station were determined in 1954-69 $\left(R^{2}=0.912\right)$ and in 1954-2010 $\left(R^{2}=0.894\right)$, respectively, and the ratio of annual sediment during the governance period and mutliyear average sediment during the base period was defined as the dynamic influencing factor of human activities. The expression is:

$$
\delta_{i}=\frac{0.449 x_{i}-5062.6}{\frac{1}{n} \sum_{i=1}^{n}\left(0.4436 x_{i}-4559.9\right)}
$$

...where $x_{i}$ represents the runoff amount in the $i$-th year $\left(10^{4} \mathrm{~m}^{3}\right)$ and $n$ is the number of years. In summary, the dynamic model of erosion-type NPS pollution was finally determined as follows:

$$
\begin{aligned}
L_{n, i}=\delta_{i} & \times\left(\frac{q_{i}}{q}\right)^{1.45} \times R_{i} \times \lambda \times A \times K \times L S \times B \times \\
& \times E \times T \times C_{n} \times \eta_{n}
\end{aligned}
$$

... where $\lambda=\lambda_{q} \cdot \lambda_{m}$ represents the average sediment delivery ratio and the average $\lambda$ value is determined as 0.92 according to the existing research results in the Loess Plateau [40-41]. $B, E$, and $T$ represent the multi-year average value of the watershed.

\section{Determining Model Factors}

In this study, a modified daily rainfall erosivity model [42] is used to calculate spatial and temporal distributions of $R$ factor [43]; the $K$ value and its spatial distribution are calculated by the modified method of soil erodibility [44] (the average $K$ value is 0.0542 ); spatial distributions of the topography factor $(L S)$ are respectively calculated by the existing formulas [45-46] (the average $L S$ value is 12.9); the existing research results of the biological measuring factor, the engineering measure factor, and tillage measuring factor in the Loess Plateau are used to spatially calculate the $B E T$ factor [47-51] (the average BET value is 0.0553 ). Based on the study results in six tributaries of the Yellow River (including the Huangfuchuan, Kuye, Wuding, Weihe, Jinghe, and Luohe rivers [52, 53], the enrichment ratio of TN was assigned to 0.671 , and the soil $\mathrm{TN}$ background contents are from the national survey data of soil nutrients.

\section{Results and Discussion}

\section{Validation of the Established Model}

Firstly, the observed values of sediment yield in Ganguyi Hydrological Station (Fig. 1c) and the simulated values in the Yanhe River watershed from 1995 to 2012 both showed a decreasing trend, although there were slight fluctuations in individual years (Fig. 2). The observed value of the annual average sediment yield modulus from 1995 to 2012 is 3,411.53 $\mathrm{t} /\left(\mathrm{km}^{2}\right.$.a) in Ganguyi hydrological station, and the simulated value in the Yanhe River watershed is 2,915.36 t/ $\left(\mathrm{km}^{2}\right.$.a) from 1995 to 2012 (the relative error is $14.5 \%$; Fig. 2). So the overall changing trends of sediment yield in the study area are consistent with the background of returning farmland. Secondly, the observed data of sediment yield in Zaoyuan and Ansai hydrological stations were also used to verify the dynamic model from 2006 to 2012, and they also have good agreement with the simulated results. However, the abnormal high sediment yield amounts before and after returning farmland in 1996 and 2002 were mainly due to the agricultural engineering measures and rainstorm intensity. Specifically, the returning farmland measures had not yet formally been implemented in 1996, and 


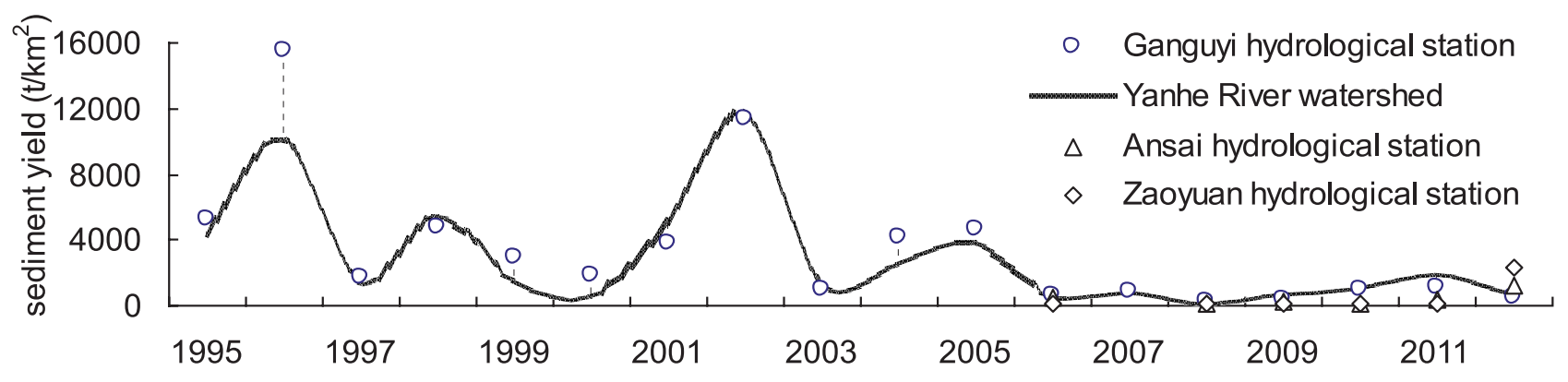

Fig. 2. Validation of sediment yield modulus between Ganguyi Hydrological Station and Yanhe River watershed.

the intensity of the rainstorm was also large; in contrast, although the returning farmland measures have partly been put into effect in 2002, the rainstorm affects are also not allowing it to be ignored this year. Thirdly, considering the similarity of the underlying surface and soil nutrients between the Yanhe River watershed and the Zhifanggou watershed in the loess hilly and gully region (Fig. 1c), the research results of annual average TN loss rules in the Zhifanggou watershed [54] were used to verify the TN simulated results. The annual average $\mathrm{TN}$ loss modulus in the Zhifanggou watershed is between $0.81-1.98 \mathrm{t} / \mathrm{km}^{2}$, the average value is $1.32 \mathrm{t} / \mathrm{km}^{2}$, the simulated value of multiyear TN load modulus in the Yanhe River watershed is $1.11 \mathrm{t} / \mathrm{km}^{2}$, and the relative error is $15.91 \%$. The above comparative analysis indicates that the established model has strong practical application value and can be used to predict dynamic changes of erosion-type NPS pollution load in the loess hilly-gully region.

\section{Temporal Variations of Adsorbed TN Load}

Fig. 3 shows that the changing trends of adsorbed NPS TN load basically coincide with the sediment yield load. The NPS TN load in the study area has an overall decreasing trend from 1995 to 2012, the reason for the decreasing trend could be mainly attributed to the extensive implementation of water conservation measures. Since the late 1990s, a lot of targeted returning farmland projects have been implemented in the Yanhe River watershed. In the early stage of water conservation projects, the soil erosion levels in the Yanhe River watershed were not improved effectively, and NPS pollution was relatively serious. With the continuous increasing of implementation intensity, the sediment yield capacity of the Yanhe River watershed has been decreasing year by year and the overall reduction benefits of sediment were remarkable. Therefore, although the NPS TN load values were relatively large in individual years, they showed an overall downward trend. The average TN load in the most recent four years (2009-12) were $2719.7 \mathrm{t} / \mathrm{a}$, which decreased by about $80.7 \%$ compared with the initial period of the Returning Farmland Project (1995-98). Results fully demonstrate that the effective implementation of soil and water conservation measures in recent decades has significant benefits on water and sediment reduction, which plays a more important role on the control of NPS pollution load.

\section{Spatial Distributions of Adsorbed TN Load}

Fig. 4 shows spatial distribution of adsorbed NPS TN load modulus in the Yanhe River watershed in 1995 and 2010. It can be seen that the high-risk regions of TN loss mainly occurs along the main river banks of the Yanhe River watershed from northwest to southeast, and gradually decreases with the increase of distance to the left and right river banks, respectively, which indicates that the spatial variations of NPS pollution are also closely related to spatial characteristics of rainfall, topography, soil, and land use types. The rapid lowering of TN load in 2010 resulted from the large-scale returning farmland measures, while compared with 1995 the effective implementation of the Returning Farmland Project significantly decreased the TN load modulus northwest of the watershed in 2010 , which shows that the sediment reduction effects of soil and water conservation measures are obvious. The spatial

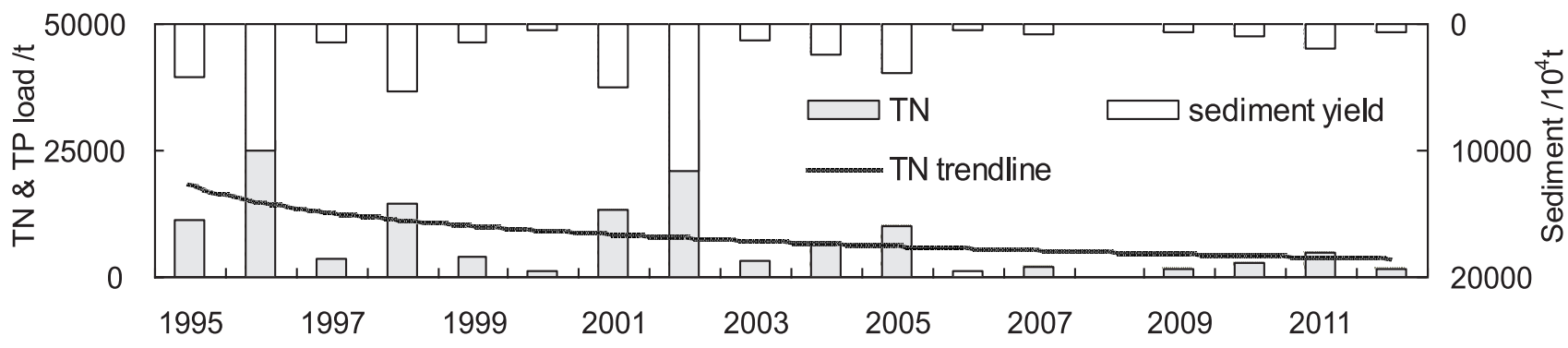

Fig. 3. Changes of adsorbed TN and sediment yield in the Yanhe River watershed from 1995 to 2012. 
a)

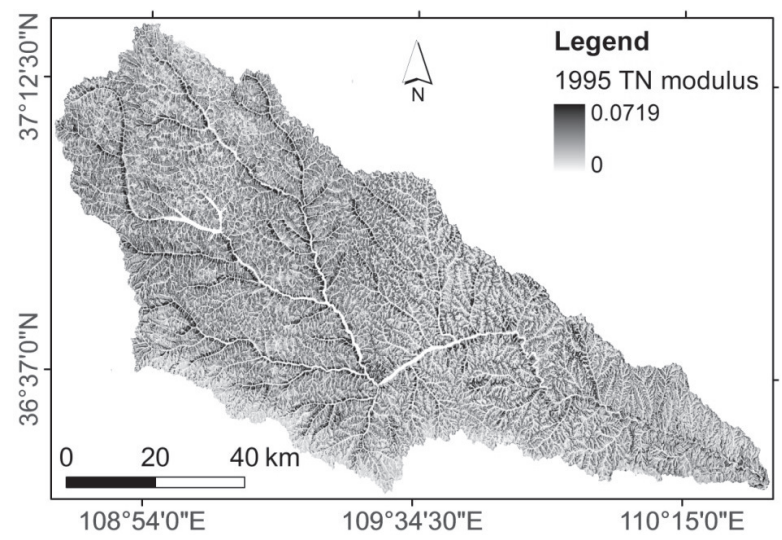

b)

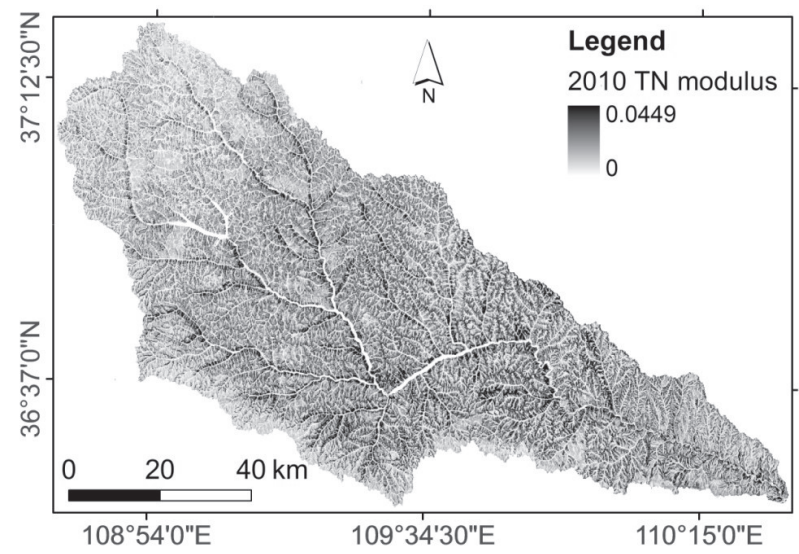

Fig. 4. Spatial distributions of adsorbed total nitrogen (TN) load modulus in 1995 and 2010 in the Yanhe River watershed $\left(\mathrm{t} / \mathrm{hm}^{2} \cdot \mathrm{a}\right)$. distribution of TN loss modulus in 1995 and 2010 is mainly based on soil erosion and closely depends on the distribution pattern of sediment yield in the corresponding years. Therefore, it has important practical significance to cut down NPS pollution load and to improve regional water quality by strengthening the relationship mechanism research between nutrient loss and the construction of soil and water conservation projects.

\section{Spatiotemporal Changes of Adsorbed TN Load in Different Land Use Types}

Figs 5 and 6 show spatiotemporal changes of the adsorbed TN load contribution ratio for each load level in different land use types of the Yanhe River watershed in 1995 and 2010. It can be seen that dry land, and low and middle coverage grassland are three main land use types of the watershed that account for $43.35 \%, 28.09 \%$, and $17.27 \%$ in 1995 , and $40.12 \%, 21.15 \%$, and $23.38 \%$ in 2010, respectively. Also, dry land, and low and middle coverage grassland are three main critical source areas of adsorbed TN load from 1995 to 2010, with spatial distribution patterns of land use types being the main reasons for spatiotemporal variations of adsorbed $\mathrm{TN}$ load. As far as each TN load level is concerned, before returning farmland in 1995, the large contribution ratios of TN load are mainly from dry land, middle-coverage grassland, low-coverage grassland, and shrub land. The middle level of TN load in dry land accounts for $73.798 \%$ of the total load, the mild level of TN load in dry land accounts for $31.724 \%$ of the total load, and the micro level of TN load in middle coverage grassland is about $33.714 \%$ of the load. With the increase of TN load level in 1995,

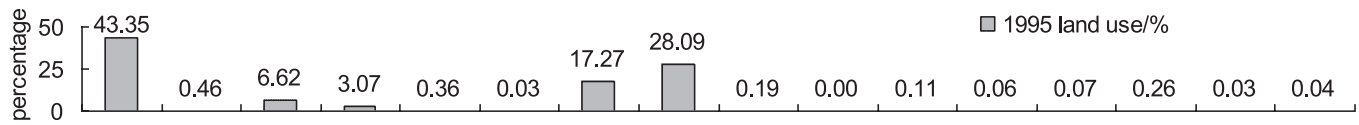

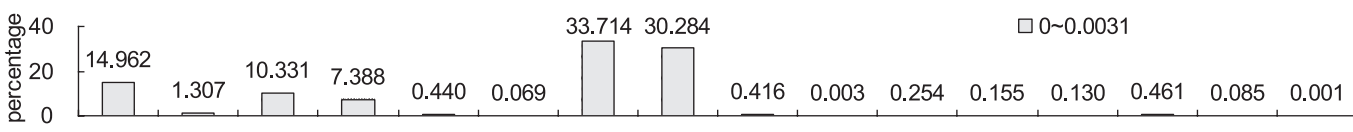

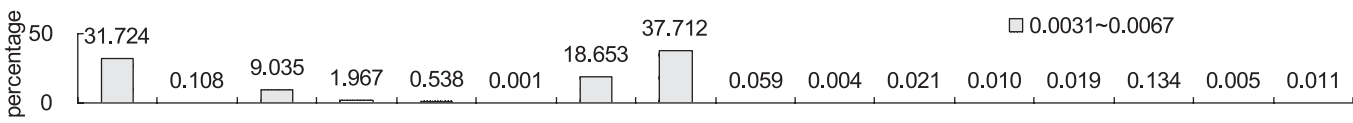

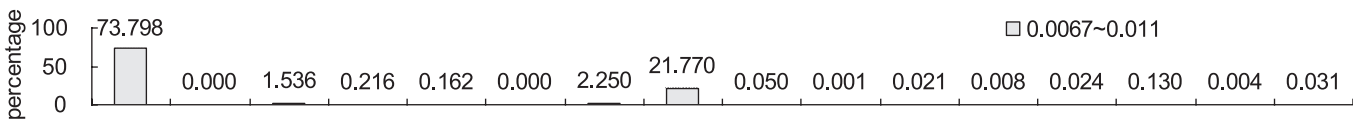

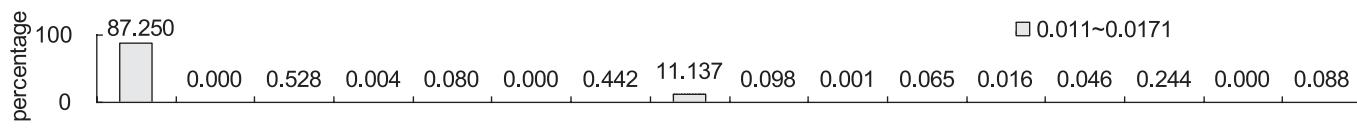

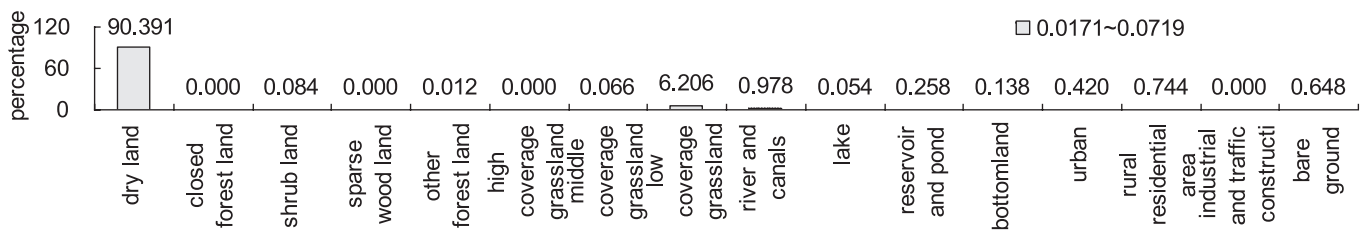

Fig. 5. TN load contribution rates for each load gradation $\left(\mathrm{t} / \mathrm{hm}^{2} \cdot \mathrm{a}\right)$ in different land use types of the Yanhe River watershed in 1995. 

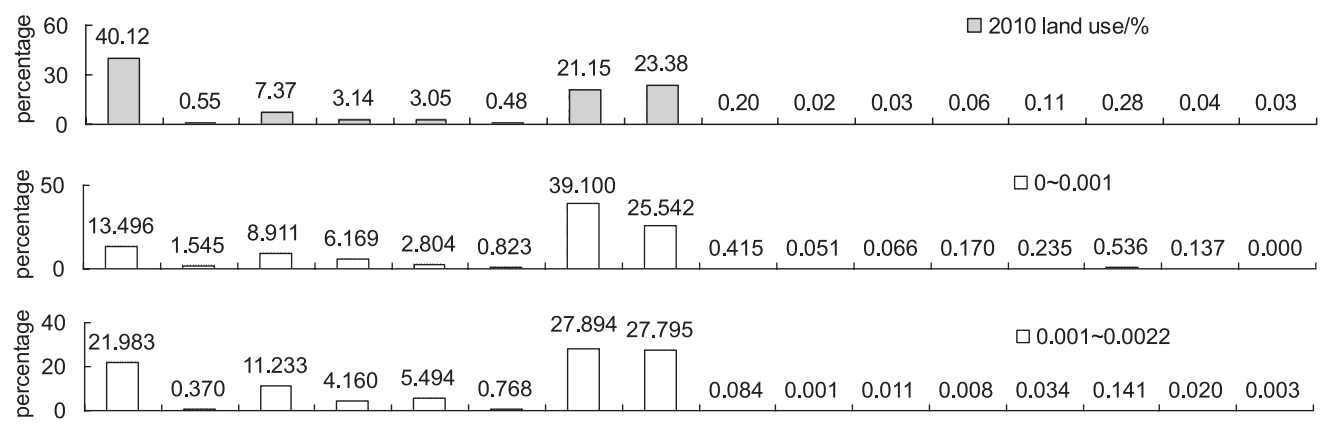

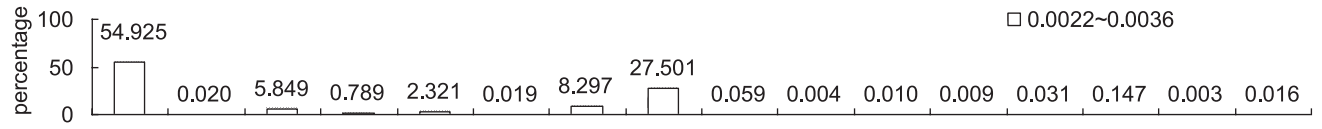

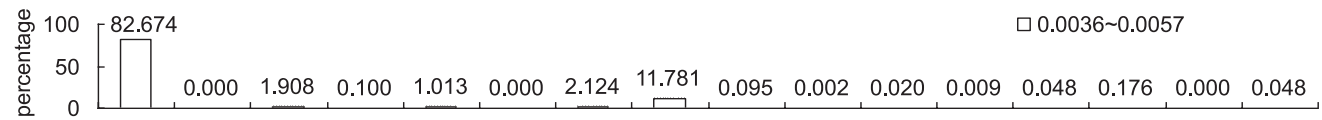

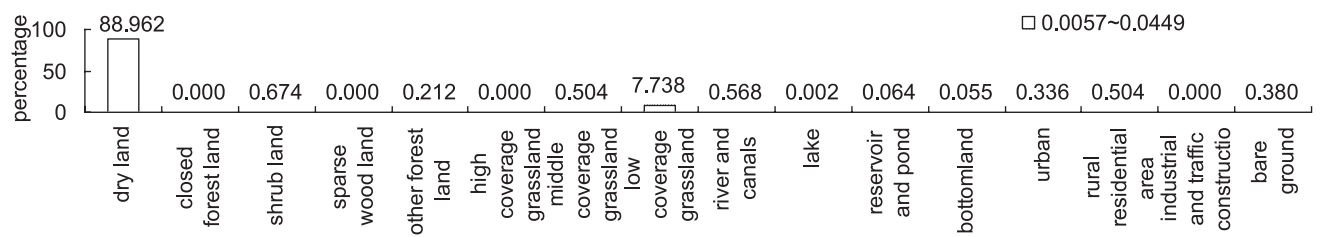

Fig. 6. TN load contribution rates for each load gradation $\left(\mathrm{t} / \mathrm{hm}^{2} \cdot \mathrm{a}\right)$ in different land use types of the Yanhe River watershed in 2010.

the contribution ratio of dry land gradually occupies the leading position, and the contribution ratio also changes from $14.962 \%$ to $90.391 \%$.

After returning farmland in 2010 , it can be seen from Fig. 6 that percentages of TN load contribution rate for each load level have similar trends with 1995. Although the contribution ratio of dry land also gradually holds the leading position, the corresponding contribution ratio decreased from $90.391 \%$ to $88.962 \%$. The TN load contribution rates for each load level in dry land all present a decreasing trend. However, the TN load contribution rates in middle coverage grassland all show an increasing trend due to land use changes from 1995 to 2010, and the TN load contribution rate for a high load level of low coverage grassland increases from $6.206 \%$ to $7.738 \%$.

The above results indicate that changes of $\mathrm{TN}$ load contribution ratio before and after returning farmland are not only related to land use changes, but also closely related to the rainfall conditions in different hydrological years. Dry land is the critical source area of NPS pollution load in the loess hilly and gully region, and the following is the middle and low coverage grassland, so reasonable agricultural conservation practices for sloping farmland are very important for the effective control of NPS pollution in the loess hilly and gully region.

\section{Control Strategies of Adsorbed NPS Pollution}

The phenomena of soil erosion and NPS pollution are inseparable in nature. Soil erosion is the major occurrence form, especially in the loess hilly and gully region in China [55]. So the sediment resulting from soil erosion is not only a kind of important NPS pollution, but also the nutrients and pollutants (organic matter, heavy metal, ammonium ion, and other toxic substances) carried by sediment may bring adverse effects on water quality of receiving waters. Soil erosion and NPS pollution are generally a combined result of many influencing factors, including climate, topography, land use types, and soil conditions [56]. China's water conservation measures (biological measures: afforestation, growing grass, etc.; engineering measures: terrace, warp land dam, and fishscale pits, etc.; tillage measures: contour tillage, rotation, intercropping, etc.) have been implemented for many years and this project has achieved great success in the comprehensive management of the loess hilly region, they have accumulated rich experiences on prevention and control of soil loss and formed a more complete system of soil loss control measures [57-58]. Because of the significant correlation between soil erosion and NPS pollution, these water conservation measures also play constructive effects on the control of NPS pollution [59]. Based on the above analysis, some measures for the management of NPS pollution can be summarized into these points: nutrient management, conservation tillage, contour farming, terrace, returning farmland to forest or grassland, contour buffer strips, and riparian forest buffer, etc. Therefore, the implementation of water conservation measures is of great significance for the control of erosion-type NPS pollution and improving the ecological environment. 


\section{Conclusions}

1. A distributed dynamic model of erosion-type NPS pollution was established to evaluate impacts of the returning farmland project on spatiotemporal characteristics of adsorbed TN pollution load in a highly erodible watershed of the loess hilly and gully region from 1995 to 2012 . Validation results indicate that the established model has characteristics of simple algorithm, wide applicability, and easy popularization, and can be used to estimate sediment yield amount of the Loess Plateau.

2. The erosion-type NPS TN load showed an overall decreasing trend since the implementation of the returning farmland project from 1997, and the average TN load in the last four years (2009-12) was $2719.7 \mathrm{t} / \mathrm{a}$, which decreased by about $80.7 \%$ compared with the initial period of treatment (199598). However, the situation of soil and nutrient loss is still very serious during heavy rain, and soil erosion is the main reason for the high TN load of the Yanhe River watershed.

3. The high risk probability value of TN loss mainly occurs in the gentle sloping farmland along the main river banks of the Yanhe River watershed from northwest to southeast, and gradually decreases with the increase of distance to the river banks. The spatial distribution patterns of TN loss in 1995 and 2010 basically depend on the distribution of sediment yield, with the TN loss of the northwestern area in 2010 significantly lower than in 1995. Dry land is the critical source area of TN NPS pollution load in the loess hilly and gully region, and soil and water conservation measures have obvious mitigation effects on soil erosion and NPS nitrogen loss.

\section{Acknowledgements}

This study was supported by the:

- National Natural Science Foundation of China (51679206, 51309194)

- International Science and Technology Cooperation Fund (A213021603)

- Fundamental Research Funds for Central Universities (2452016120)

- 2014 College Student Innovation and Entrepreneurship Training Plan Innovation Training Project (201410712091)

- Special Research Foundation for Young Teachers (2452015374)

- Open Foundation of State Key Laboratory, Institute of Soil and Water Conservation, Chinese Academy of Sciences and Ministry of Water Resources (K318009902-1417)

- Doctoral Fund of Ministry of Education of China (20130204120034)

- Initial Scientific Research Funds for Ph.D. from Northwest A\&F University (2012BSJJ004)
- Fundamental Research Funds for the Central Universities (QN2013047)

\section{References}

1. SHI H. Non point source pollution of soil and water loss. Bulletin of Soil and Water Conservation, 17 (7), 99, 1997.

2. CHEN L.D., WANG J.P., WEI W., FU B.J., WU D.P. Effects of landscape restoration on soil water storage and water use in the Loess Plateau Region, China. Forest Ecology and Management, 259 (7), 1291, 2010.

3. REN M.E. Sediment transport in the Yellow River: yesterday, today and tomorrow: Sediment budget of the Yellow River since 150 thousand years ago. Advances in Earth Sciences, 21 (6), 552, 2006.

4. WANG Q.J., WANG H., GUO T.L. Characteristics and mathematical model of soil solute transport and surface runoff on Loess Slope. Beijing: Science Press, 2010.

5. JIANG T.T. Simulation study on the amount of adsorbed $\mathrm{N}$ and $\mathrm{P}$ in soil of Hubei Province. Hebei: Agricultural University Of Hebei, 1, 2010.

6. ZHENG F.L., LIU F., YANG Q.K., JIANG Z.S. Research progress of soil erosion prediction model. Bulletin of Soil and Water Conservation, 21 (6), 16, 2001.

7. GENG R.Z., LI M.T., WANG X.Y., PANG S.J. Effect of land use/landscape changes on diffuse pollution load from watershed based on SWAT model. Transactions of the Chinese Society of Agricultural Engineering (Transactions of the CSAE), 31 (16), 241, 2015.

8. HUANG J.J., LIN X.J., WANG J.H., WANG H. The precipitation driven correlation based mapping method (PCM) for identifying the critical source areas of non-point source pollution. Journal of Hydrology, 524, 100, 2015.

9. SILGRAM M., ANTHONY S.G., COLLINS A.L., STROMQVIST J., BOURAOUI F., SCHOUMANS O., LO PORTO A., GROENENDIJK P., ARHEIMER B., MIMIKOUF M., JOHNSSONG H. Evaluation of diffuse pollution model applications in EUROHARP catchments with limited data. Journal of Environmental Monitoring, 11 (3), 554, 2009.

10. WANG C.H., ZHAO D.Z., CAO B., LIANG D.Y. Research on Simulation of Non point Source Pollution in Qingjiang River Basin Based on SWAT Model and GIS. Journal of Yangtze River Scientific Research Institute, 27 (1), 57, 2010.

11. RENARD K.G., FOSTER GR, WEESIES GA, MCCOOL DK, YODER DC. Predicting soil erosion by water: a guide to conservation planning with the revised universal soil loss equation (RUSLE) (p.404). Washington: US Department of Agriculture, Agriculture Handbook, No.703, Agriculture Research Service, 2007.

12. WU L., LIU X., MA X.Y. Tracking soil erosion changes in an easily-eroded watershed of the Chinese Loess Plateau. Polish Journal of Environmental Studies, 25 (1), 332, 2016.

13. LIU B.Y., XIE Y., ZHANG K.L. Soil erosion prediction model. Beijing: Chinese Science and Technology Press, 2001.

14. FU S.H., ZHANG W.G., LIU B.Y., ZHU Q.J., WU J.D., DUAN S.H., LI Y.G. Beijing mountain area soil erosion model. Research of Soil and Water Conservation, 8 (4), 114, 2001.

15. CHENG L., YANG Q.K., XIE H.X. Quantitative evaluation method of soil erosion in Shaanxi Province Based on GIS and CSLE. Journal of Soil and Water Conservation, 23 (5), 61, 2009. 
16. SHI Z.H., CAI C.F., DING S.W., LI Z.X., WANG T.W., ZHANG B., SHENG X.L. Research on nitrogen and phosphorus load of agricultural non-point sources in middle and lower reaches of Hanjiang River besed on GIS. Acta Scientiae Circumstantiae, 22 (4), 473, 2002.

17. XUE J.F., XIA J., LIANG T., ZHANG X.M. Research on load model of particular nitrogen and phosphorus. Advances in Water Science, 16 (3), 334, 2005.

18. LONG T.Y., LIU L.M., LI C.M., LI J.C. A GIS-Based Study of the Pollution Load of Adsorbed Nitrogen and Phosphorus in Jialing River Basin, P. R. China. Journal of Chongqing Jianzhu University, 30 (3), 87, 2008.

19. HUANG G.R., YAO X.L., HU H.Y. Research on Methods of Agricultural Non-point Source Pollution Load Calculation. Water Resources \& Power, 29 (11), 28, 2011.

20. YU J.X., ZHENG B.F., LIU Y.F., LIU C.L. Evaluation of soil loss and transportation load of adsorption $\mathrm{N}$ and $\mathrm{P}$ in Poyang Lake watershed. Acta Ecologica Sinica, 31 (14), 3980, 2011.

21. WU L., LONG T.Y., LIU X., MA X.Y. Modeling impacts of sediment delivery ratio and land management on adsorbed non-point source nitrogen and phosphorus load in a mountainous basin of the Three Gorges reservoir area, China. Environmental Earth Sciences, 70 (3), 1405, 2013.

22. EROL A., EKINCI K., AKBOLAT D., EVRENDILEK F. Modeling Impacts of Land Uses on Carbon and Nitrogen Contents, Carbon Dioxide and Water Effluxes of Mediterranean Soils. Polish Journal of Environmental Studies, 25 (4), 1479, 2016.

23. ÖZTÜRK M., COPTY N.K., SAYSEL A.K. Modeling the impact of land use change on the hydrology of a rural watershed. Journal of Hydrology, 497, 97, 2013.

24. LI T.H., ZHENG L.N. Soil erosion changes in the Yanhe River watershed from 2001 to 2010 based on RUSLE model. Journal of Natural Resources, 27 (7), 1164, 2012.

25. LI M.T., WANG X.Y., LIU W.Z. Relationship between landscape pattern and non-point source pollution loads in the Chaohe River Watershed. Acta Scientiae Circumstantiae, 33 (8), 2296, 2013.

26. OUYANG W., HUANG H., HAO F., GUO B. Synergistic impacts of land-use change and soil property variation on non-point source nitrogen pollution in a freeze-thaw area. Journal of Hydrology, 495, 126, 2013.

27. SAJIKUMAR N., REMYA R.S. Impact of land cover and land use change on runoff characteristics. Journal of Environmental Management, 161, 460, 2015.

28. SIMONNEAUX V., CHEGGOUR A., DESCHAMPS C., MOUILLOT F., CERDAN O., BISSONNAIS Y.L. Land use and climate change effects on soil erosion in a semi-arid mountainous watershed (High Atlas, Morocco). Journal of Arid Environments, 122, 64, 2015.

29. XIAO H., JI W. Relating landscape characteristics to nonpoint source pollution in mine waste-lacated watersheds using geospatial techniques. Journal of Environmental Management, 82 (1), 111, 2007.

30. ZUO D.P., XU Z.X., YAO W.Y., JIN S.Y., XIAO P.Q., RAN D.C. Assessing the effects of changes in land use and climate on runoff and sediment yields from a watershed in the Loess Plateau of China. Science of the Total Environment, 544, 238, 2016.

31. XIE H.X., LI R., YANG Q.K., LI J., LIANG W. Effects of returning farmland to forest (pasture) and changes of precipitation on soil erosion in the Yanhe basin. Scientia Agricultura Sinica, 42 (2), 569, 2009.

32. REN Z.P., ZHANG G.H., YANG Q.K. Characteristics of runoff and sediment variation in Yanhe River basin in last 50 years. Journal of China Hydrology, 32 (5), 81, 2012.
33. LI J.C. Simulation of non-point source pollution load in the Jialing River Basin. Chongqing: Chongqing University, 1, 2007.

34. WU L., LIU X., MA X.Y. Application of a modified distributed-dynamic erosion and sediment yield model in a typical watershed of a hilly and gully region, Chinese Loess Plateau. Solid Earth, 7 (6), 1577, 2016.

35. PROSSER I.P., RUSTOMJI P. Sediment transport capacity relations for overland flow. Progress in Physical Geography, 24, 179, 2000.

36. XU X.X., GAO C.X., ZHAO J.N. Trends of runoff and sediment load of Yanhe River basin and their related driving forces during 1956-2009. Journal of Sediment Research, 2, $12,2012$.

37. GAO P., ZHANG X.C., MU X.M., WANG F., LI R., ZHANG X.P. Trend and change-point analyses of streamflow and sediment discharge in the Yellow River during 1950-2005. Hydrological Sciences Journal, 55 (2), 275, 2010.

38. LI C.Z., WANG H., YU F.L., YANG A.M., YAN D.H. Impact of soil and water conservation on runoff and sediment in Yanhe River Basin. Science of Soil and Water Conservation, 1, 1, 2011.

39. WANG G., FAN Z. Study on changes of water and sediment in the Yellow River (Vol. 1). Zhengzhou: Yellow River Water Conservancy Press, 623, 2002.

40. JING K., WANG W.Z., ZHENG F.L. Soil erosion and environment in China. Beijing: Science Press, 1, 2005.

41. ZHU H.F., KANG M.Y., ZHAO W.W., GUO W.W. Effects of soil and water conservation measures on erosion, sediment delivery and deposition in Yanhe River Basin. Research of Soil and water conservation, 14 (4), 1, 2007.

42. ZHANG W.B., XIE Y., LIU B.Y. Spatial variation characteristics of rainfall erosion in China. Journal of Mountain Science, 21 (1), 33, 2003.

43. WU L., MAX.Y. Research progress in erosion-type nonpoint source pollution process simulation of the Loess Plateau. China Sciencepaper, 10 (13), 1497, 2015.

44. ZHANG K.L., PENG W.Y., YANG H.L. Soil erodibility and its estimation for agricultural soil in China. Acta Pedologica Sinica, 44 (1), 7, 2007.

45. LIU B.Y., BI X.G., FU S.H. Beijing soil loss equation. Beijing: Science Press, 52, 2010.

46. MCCOOL D.K., BROWN L.C., FOSTER G.R., MUTCHLER C.K., MEYER L.D. Revised slope steepness factor for the Universal Soil Loss Equation. Transaction of the ASAE, 30 (5), 1387, 1987.

47. Soil and water conservation monitoring center (Ministry of Water Resources). A report on the development project of soil erosion prediction model in the Northwest Loess Plateau, 2006.

48. ZHANG Y., LIU B.Y., SHI P.J., JIANG Z.S. Crop cover factor estimating for soil loss prediction. Acta Ecologica Sinica, 21 (7), 1050, 2001.

49. ZHANG Y., YUAN J.P., LIU B.Y. Research progress of vegetation cover and management factor in soil erosion prediction model. Chinese Journal of Applied Ecology, 13 (8), 1033, 2002.

50. WANG W.Z., JIAO J.Y. Quantitative assessment of soil erosion factors in China. Bulletin of Soil and Water Conservation, 16 (5), 1, 1996.

51. XIE H.X. Evaluation and research on temporal and spatial variation of soil erosion and environmental effects of soil and water conservation in Yanhe Basin. Xi'an: Shaanxi Normal University, 1, 2008. 
52. YU D.S., SHI X.Z. Spatial distribution data set of 1:400 million soil chemical properties in China. National Data Sharing Infrastructure of Earth System Science, 2007.

53. HAN F.P., ZHENG J.Y., ZHANG X.C. Distribution status of non-point source pollution in six sub basins of the Yellow River. Journal of Northwest A\&F University (Natural Science Edition), 34 (8), 75, 2006.

54. ZHANG X.C., SHAO M.A. Soil erosion loss by erosion as affected by vegetation cover and cpmprehensive managements in Zhifanggou catchment of hilly Loess Plateau. Acta Geographica Sinica, 55 (5), 617, 2000.

55. WU L., LIU X., MA X.Y. Spatio-temporal variation of erosion-type non-point source pollution in a small watershed of hilly and gully region, Chinese Loess Plateau. Environmental Science and Pollution Research, 23, 10957, 2016.
56. LV X.Z., YU X.X., FAN D.X., LI Q.Y. Estimation of nonpoint source pollution loads caused by soil erosion in China. Journal of Food, Agriculture \& Environment, 10 (2), 1045, 2012.

57. LI Q.H., LI C.Z., SUN B.P., SUN L.D. Prediction and control of soil erosion and non-point sources pollution. Bulletin of Soil and Water Conservation, 19 (4), 54, 1999.

58. LIU B.Y., LIU Y.N., ZHANG K.L., XIE Y. Classification for soil conservation practices in China. Journal of Soil and Water Conservation, 27 (2), 80, 2013.

59. TRIPATHI M.P., PANDA R.K., RAGHUWANSHI N.S Identification and prioritization of critical sub-watersheds for soil conservation management using the SWAT model. Biosystems Engineering, 85 (3), 365, 2003. 